\title{
The Role of Community-Led Food Retailers in Enabling Urban Resilience
}

\author{
Morven G. McEachern ${ }^{1}$ * $*$ D , Gary Warnaby ${ }^{2}$ and Caroline Moraes ${ }^{3}$ (D) \\ 1 Department of Management, University of Huddersfield, Huddersfield HD1 3DH, UK \\ 2 Business School, Metropolitan University, Manchester M15 6BH, UK; g.warnaby@mmu.ac.uk \\ 3 Department of Marketing, University of Birmingham, Birmingham B15 2TT, UK; c.moraes@bham.ac.uk \\ * Correspondence: m.mceachern@hud.ac.uk
}

Citation: McEachern, M.G.; Warnaby, G.; Moraes, C. The Role of

Community-Led Food Retailers in

Enabling Urban Resilience.

Sustainability 2021, 13, 7563

https://doi.org/10.3390/su13147563

\section{Academic Editors:}

Herculano Cachinho and

Teresa Barata-Salgueiro

Received: 15 June 2021

Accepted: 1 July 2021

Published: 6 July 2021

Publisher's Note: MDPI stays neutral with regard to jurisdictional claims in published maps and institutional affiliations.

Copyright: (c) 2021 by the authors. Licensee MDPI, Basel, Switzerland. This article is an open access article distributed under the terms and conditions of the Creative Commons Attribution (CC BY) license (https:/ / creativecommons.org/licenses/by/ $4.0 /)$.

\begin{abstract}
Our research examines the extent to which community-led food retailers (CLFRs) contribute to the resilience and sustainability of urban retail systems and communities in the UK, contributing to existing debates on the sustainability and resilience of the UK's urban retail sector. While existing literature has predominantly focused on larger retail multiples, we suggest more attention be paid to small, independent retailers as they possess a broader, more diffuse spatiality and societal impact than that of the immediate locale. Moreover, their local embeddedness and understanding of the needs of the local customer base provide a key source of potentially sustainable competitive advantage. Using spatial and relational resilience theories, and drawing on 14 original qualitative interviews with CLFRs, we establish the complex links between community, place, social relations, moral values, and resilience that manifest through CLFRs. In doing so, we advance the conceptualization of community resilience by acknowledging that in order to realise the networked, resilient capacities of a community, the moral values and behavior of the retail community need to be ascertained. Implications and relevant recommendations are provided to secure a more sustainable set of capacities needed to ensure resilient, urban retail systems which benefit local communities.
\end{abstract}

Keywords: community resilience; food retailing; retail resilience; sustainability; moral values; urban

\section{Introduction}

This study is set within a context of academic and NGO debates around the sustainability and resilience of the retail sector [1-3]. Consequently, our research examines how community-led food retailers contribute to the resilience and sustainability of urban retail systems and communities in the UK. In particular, researchers have questioned the contentious relationships between large retail organisations and suppliers [4], the damaging environmental impact of traditional retailers' business models [5], and the role of large retail organizations in encouraging unsustainable consumption behaviours [6-8]. Focusing specifically on grocery retail, Robbins and Page [9] (p. 176) criticise retailers' sustainability initiatives, including codes of conduct for suppliers and ethical food and drink certifications that are not verified independently, for the "mismatch between the magnitude of the problem and the shallow incrementalism-even opportunism" of such activities. Furthermore, questions continue to be asked about the compatibility between large food retailers' visions of growth (e.g., exploitation of new geographical markets, or the creation of new retail formats, often termed "express" or "local", that directly compete with existing independent food shops) and their sustainability [10-12].

This increased scrutiny has shed light on issues that are symptomatic of a concentration of power, whereby "retailing has been transformed ... from a predominantly independent-based sector to one where multinational chains and strong national retailers are economically dominant" $[13,14]$. In the UK, these tendencies have been particularly evident in the grocery sector, widely regarded as oligopolistic, leading to long-standing concerns about its socio-economic implications [15]. Retail chains can have negative impacts 
on traditional urban centres, resulting from changes in consumers' shopping behaviours that these retailer strategies have sought to shape $[16,17]$. The growth of the convenience sector and the impact of the "corporate convenience store" [18] have also had a significant effect on urban food consumption behaviours, contributing to the gentrification of some urban areas and food deserts in others. More recently, this retail disaggregation and decentralisation has meant that retailers have become "increasingly divorced" from the communities they once served [3] (p. 10).

By contrast, we argue that more attention be paid to small, independent retailers as they possess a much broader and more diffuse spatiality beyond that of the immediate locale. Therefore, our focus in this paper is the range of what we describe as community-led food retailers (CLFRs), such as social supermarkets, food co-operatives, and social food enterprises, which also include community interest companies (CICs). We define CLFRs as retail organizations that challenge the dominant modus operandi of large food retailing $[5,19]$ and contribute to "efforts to re-embed food production and consumption within a social system" [5] (p. 562). Given their underlying ethos, in this paper we investigated the role of CLFRs and sought to answer the following research question: to what extent can such businesses contribute to the resilience and sustainability of the more traditional retail systems of UK towns and cities, and those of their communities?

We addressed this research question by drawing on spatial and relational theories of resilience, to advance existing debates on the sustainability of urban retail in the UK. Our focus on the UK is justified given its status as one of the most developed and dynamic retail marketplaces in the world [20], as well as the increased need for retailers and communities to respond and adapt quickly to changing urban market conditions in light of the resilience challenges arising from a range of external forces, such as-most recentlyCOVID-19-related restrictions. Moreover, Nguyen and Akerkar [21] call for further efforts to understand community resilience. In response to such challenges and calls for research, we contributed to these theories by providing original insight into urban CLFRs and the complex links between community, place, social relations, morality, and resilience. More specifically, we advanced Norris et al.'s [1] conceptualization of community resilience by recognizing that in order to realise the networked, resilient capacities of a community, the moral values and behavior of the retail community need to be ascertained. This theoretical contribution is significant as it illuminates the more sustainable set of capacities needed to ensure resilient, urban retail systems, which benefit local communities.

We begin by contextualizing our study with an overview of the urban retail environment before moving to describe CLFRs in more detail. This is followed by a discussion of the theoretical concepts of urban and community resilience.

\section{Literature Review}

\subsection{Urban Retailing and Community-Led Food Retailers (CLFRs)}

Much of the food retail literature is categorised as either focusing on large multiple retailers or small, independent, and convenience food retailers. Resulting discourses regarding the latter largely concentrate on the operational and spatial difficulties they experience in the face of competitive market entry strategies and greater economies of scale from large retail multiples [22] and the strategic opportunities available to small, independent, and convenience food retailers to counteract any further loss of market share $[23,24]$. The importance of place and the social role of the small, independent retailer is also acknowledged, albeit with a focus on operational differences between rural and urban retailers [11,25,26]. However, McArthur et al. [27] (p. 281) argue that the retail sector cannot be fully understood without reflecting upon the "interrelated systems of which it is a part". That is to say, the place providing a spatial and economic context, the moral and social relations, and community competencies inherent within, are paramount to the retailer's success.

There has been limited research inquiry into CLFRs, their sustainability-related operations, or their resilience. Existing literature indicates that such CLFRs can be defined 
as businesses that usually stand for shared values and seek to address the perceived shortcomings of dominant retail systems of food provision to overcome issues related to environmental concerns, poor taste and lack of seasonality, food illiteracy, and food-related social injustice [5]. Table 1 summarises the main types of CLFR in operation within the UK retail marketplace.

For example, regarded as an innovative retail approach that is geared towards the provision of goods and services for the financially vulnerable [28], social supermarkets operate largely in more disadvantaged communities. Similarly, while small, independent urban retailers may also provide a "sense of community or identity both for a place and for its inhabitants" [26] (p. 208), few retail studies acknowledge these community and identity-building roles. Consequently, existing literature treats urban retailers' community and identity-building functions generally as an "exogenous part of the environment" when, in fact, community and identity should be recognised as being "completely endogenous to the enterprise" [29] (p. 310).

Table 1. Main Types of CLFRs and Definitions.

\begin{tabular}{|c|c|}
\hline CLFR Type & Definition \\
\hline Social Supermarket & $\begin{array}{c}\text { A supermarket that "receives surplus food and consumer goods from } \\
\text { partnership companies (e.g., manufacturers, retailers) for free and } \\
\text { will sell it at symbolic prices to a restricted group of people living in } \\
\text { or at risk of poverty" [19] (p. 2). }\end{array}$ \\
\hline \multirow[t]{4}{*}{ Co-operative } & $\begin{array}{l}\text { An "autonomous association of persons united voluntarily to meet } \\
\text { their common economic, social and cultural needs and aspirations } \\
\text { through a jointly owned and democratically controlled enterprise" } \\
\text { [30] (p. 12). Common types of co-operative and their definitions are } \\
\text { given below. }\end{array}$ \\
\hline & $\begin{array}{l}\text { Worker co-operatives are run by the workers, have flat structures and } \\
\text { no hierarchy. All workers are involved in the decision-making. }\end{array}$ \\
\hline & $\begin{array}{l}\text { Consumer co-operatives exist to serve the needs of the customers, } \\
\text { e.g., Credit Unions. }\end{array}$ \\
\hline & $\begin{array}{l}\text { Community co-operatives raise finance through community shares, } \\
\text { and it is run for the benefit of the community. }\end{array}$ \\
\hline Social Enterprise & $\begin{array}{c}\text { An "independent organization with social and economic objectives } \\
\text { that aims to fulfil a social purpose as well as achieving financial } \\
\text { stability through trading" [31] (p. 3). }\end{array}$ \\
\hline Social Business & $\begin{array}{l}\text { A business that is designed to solve a social problem. It is typically } \\
\text { made up of a small group of members who act in a similar way to } \\
\text { trustees [32]. }\end{array}$ \\
\hline $\mathrm{CIC}$ & $\begin{array}{l}\text { A Community Interest Company is a type of limited company that } \\
\text { wants to use its profit and assets for public good. It generally has a } \\
\text { focus on local markets services [30]. }\end{array}$ \\
\hline
\end{tabular}

Together with Nguyen and Akerkar's [21] call for further research on community resilience, Moufahim et al. [33] urge scholars to develop a more nuanced understanding of manifestations of community in the marketplace. Thus, in this paper, we heeded this exhortation in relation to both spatial and relational aspects of resilience [34], in the context of urban retail systems.

While academic attention has been paid to food retailers such as farmer's markets, farm shops, and box delivery schemes [35,36], little attention has been dedicated to community-led retail models such as CLFRs and their ability to respond and adapt to changing urban market conditions. Arguably, the current COVID-19 pandemic throws this lack of attention into sharp relief, given the fact that, in the UK, many retailers defined as being non-essential were subject to a government-mandated lockdown for several months. Indeed, in most regions across the UK, retailers are now subject to strict social distancing 
measures which adversely affect their operations, thus retailer resilience has never been more apposite. Thus, we turned to spatial and relational theories of resilience to frame and advance our understanding of urban CLFRs and the complex links between community, place, social relations, moral values, and resilience that they enable.

\subsection{The CLFR through a Spatial and Relational Resilience Lens}

Interrelated spatial and relational resilience theories addressing both urban and community-based resilience provided a theoretical lens for our discussion of CLFRs and their potential contributions to the sustainability of urban retail systems.

\subsubsection{Understanding Urban Resilience}

In a UK context, Coaffee [37] documents four waves in the conceptualization of urban resilience in policy and planning practice, progressing from shock absorption and preventative actions, to embedding resilience and security into everyday activities, and finally to the more local, place-based resilience approaches that we focus on hereafter.

Meerow et al. [38] note we are witnessing a revitalization around resilience. Stumpp [39] (p. 164) suggests that resilience has become the new "buzzword" in urban matters; indeed, resilience has assumed greater emphasis in research and policy discourse, helping places to cope with high levels of uncertainty [37,38,40-43]. This is particularly relevant, as urban areas are theorised as highly complex, dynamic, and adaptive systems [38,41]. Yet, despite its current significance in public policy terms, there is no single consensus definition of resilience, and its conceptual boundaries remain fuzzy [38]. Consequently, resilience can be considered to be what Star and Griesemer [43] term a "boundary object" [38,44]. Acknowledging these issues, Meerow et al. [38] synthesise existing conceptualizations to articulate the following definition of urban resilience:

"the ability of an urban system-and all its constituent socio-ecological and sociotechnical networks across temporal and spatial scales-to maintain or rapidly return to desired functions in the face of a disturbance, to adapt to change, and to quickly transform systems that limit current or future adaptive capacity" [38] (p. 45).

This flexible, inclusive definition enables "different perspectives and emphases to remain and flourish" and "stakeholders to come together around a common terminology without requiring them to agree on an exact definition" [38] (p. 45). This definition also addresses a number of "important conceptual tensions apparent in the urban resilience literature" [38] (p. 39). The first relates to the conceptualization of what constitutes "urban", which for the purposes of this paper we understood as relating to, or characteristic of, a town or city.

The remaining conceptual tensions focus more specifically on the processes, perceptions, and temporal aspects inherent in resilience [38]. For example, Meerow et al.'s [38] second conceptual tension concerns distinctions between single-state equilibrium (i.e., a system's capacity to revert to a previous equilibrium, post-disturbance); multiple-state equilibrium (i.e., following a disturbance, a system may be transformed by tipping from one stable domain to another); and dynamic non-equilibrium (i.e., constant change and no singular stable state). Grinberger and Felsenstein [45] discuss similar tensions in terms of urban systems' abilities to bounce back to a former stable equilibrium or bounce forwards from urban shocks towards various potential new trajectories.

A third conceptual tension considers whether resilience is inherently positive, with an emerging debate regarding whether returning to a previous state is indeed desirable, if urban resilience refers to the ability to return to a normal or steady state after a disturbance [38]. The fourth conceptual tension outlined by Meerow et al. [38] relates to the different mechanisms or "pathways" to a resilient state, namely: persistence (i.e., resist disturbance and try to maintain the status quo); transition (i.e., incrementally adapt while retaining system function); and transformation (where efforts to build resilience may seek to purposefully change an undesired system). Meerow et al.'s [38] fifth conceptual tension 
refers to the nature of adaptation, contrasting specific adaptation(s) to known threats with more generic adaptability.

A final conceptual tension introduces a temporal dimension, with an apparent consensus existing with regard to the importance of rapid recovery post-disturbance. However, as Meerow et al. [38] state, this may be contingent upon whether the focus is on rapid-onset disasters or more gradual factors. Cutter et al. [40] suggest that the rate of onset of the urban disruption is important in understanding resilience, with distinctions between "chronic stresses", where the urban system is weakened regularly over time (e.g., climate change), and "acute shocks", where sudden events significantly disrupt an urban system, with the current pandemic-related national lockdown of non-essential retailers being one recent "acute" example [42].

The above discussion focuses on spatial aspects of resilience, with an emphasis on the urban context. However, Golubchikov [34] suggests that resilience can be both spatial and relational. Thus, resilience can be considered and experienced at a community level [46], and it is to the notion of community resilience that we now turn.

\subsubsection{Understanding Community Resilience}

Community can be thought of as a type of collectivity or social unit and as a type of social relationship or sentiment [47]. These two approaches to conceptualizing community are not mutually exclusive and also involve a spatial dimension [48]. Community as a type of collectivity "usually refers to a group sharing a defined physical space or geographical area, such as a neighborhood, city, village or hamlet" [47] (p. 114), which can be termed a territorial approach to the concept [48]. In contrast, community as a type of social relationship is defined as "a group sharing common traits, a sense of belonging, and/or maintaining social ties and interactions which shape it into a distinctive social entity" [47] (p. 114), and can be thought of in non-territorial terms [48]. These approaches can be seen as comprising different dimensions of community [48], rather than competing alternatives to conceptualizing it.

Following Baron et al. [48], in this paper we used the concept of community to incorporate both territorial and non-territorial attributes. Here, we were also mindful of Baker et al.'s [49] (p. 7) proposition that the concept of community involves three core elements: "a consciousness of kind"; the "presence of shared traditions"; and a "sense of moral obligation to the collective". It is this sense of moral obligation that helps to facilitate collective moral action in the event of any threat facing a community [50].

Within communities, resilience has typically been explored in relation to the response-and ultimately, recovery-demonstrated by collective groups to stressors and /or natural disasters such as earthquakes and tornados [1,46,51-53]. Here, the primary focus is on the community's capacity to recover from an adverse event through drawing on key information resources such as accessible, local, and trusted communication [21,54]. More recently, however, and resonating with the second of Meerow et al.'s [38] conceptual tensions of urban resilience, De Verteuil and Golubchikov [55] view resilience as an active process involving change or reinvention, and therefore acting as a precursor to securing a more transformative future. Indeed, retail pop-ups which help transform retail systems, as well as facilitate additional footfall for permanent urban retailers, are just one example of the transformation of retail space.

To help promote readiness and appropriate community responses, Norris et al. [1] propose conceptually that community resilience emerges from four adaptive capacities, namely economic development (i.e., resource volume and diversity; resource equity and social vulnerability), social capital (i.e., network structures and linkages; social support; community bonds, roots and commitments), information and communication (i.e., systems and infrastructure for informing the public; communication and communal narratives), and community competence (i.e., collective action and decision-making; collective efficacy and empowerment). While there is some overlap between these capacities (and especially between social capital and information and communication), when all capacities are 
combined, they represent a strategy for overcoming adversity and/or disaster recovery. Moreover, they provide a basis from which to "draw conclusions about the set of capacities that should become the focus of our attention in community resilience theory, research and application" [1] (p. 136).

Building on Norris et al.'s [1] conceptualization of community resilience, Nguyen and Akerkar [21] identify comparable properties, but importantly, highlight the need to address sustainability. While concepts of resilience and sustainability are multidimensional and address values-based elements required for the sustainable development of a place and/or community [2], neither Norris et al. [1] nor Nguyen and Akerkar [21] advocate the consideration of moral obligation, values, and behavior, all of which are viewed as nonessential to achieving sustainable development goals [56]. Moreover, the omission of moral values ignores their role in facilitating collective action when facing adversity and/or threats within the community [48-50].

In line with the urban resilience literature, temporality also features prominently in this context. Both Martin [57] and Szmigin et al. [53] emphasise the more ongoing and persistent processes of adaptation and reinvention taking place across time, resonating with Meerow et al.'s [38] fifth conceptual tension of urban resilience discussed previously. This signals the importance of adopting a long-term community resilience approach to overcoming and/or managing adverse events in peoples' lives.

These interrelated concepts of community and urban resilience provide a theoretical contextualisation for our discussion of CLFRs. We next discuss our methodology, before reporting our findings on the potential contributions of CLFRs to the resilience and sustainability of urban retail systems.

\section{Research Methodology}

We drew on an interpretive approach to gain an in-depth understanding of the extent to which CLFRs can maintain and/or enhance urban retail resilience. Interpretivism helps generate insights from small samples that are generalisable within theoretical propositions, rather than to populations [58-60]. In our context, insights into the interplay between morality and sustainable urban retail systems led to nuanced understandings of "qualities that describe or explain a phenomenon of theoretical interest" [59] (p. 16), and therefore, contributed to further theorization of community resilience.

Interpretive research can offer contextual understanding of CLFR issues from the pluralistic perspective of participants [61]. We carried out 14 semi-structured, in-depth qualitative interviews with owners, store managers, and/or members from urban, community-led retail organisations such as social enterprises, co-operatives, and social supermarkets. Some of the interviews included different individuals from the same business, but at other urban locations. Table 2 provides an overview of location, length of time in business, and scale of operations of the CLFRs interviewed for this research. Our purposive sample was consistent with methodological approaches that seek fine-grained, in-depth examination of a particular phenomenon [62,63] and allowed for a rich, in-depth understanding of CLFRs and their contribution to urban retail resilience to emerge [64]. 
Table 2. CLFR Characteristics.

\begin{tabular}{|c|c|c|c|}
\hline Business Pseudonym & Business Model & $\begin{array}{c}\text { Year of } \\
\text { Establishment }\end{array}$ & $\begin{array}{c}\text { Number of } \\
\text { Outlets }\end{array}$ \\
\hline CLFR 1-Manchester & $\begin{array}{l}\text { Co-operative } \\
\text { (Workers) }\end{array}$ & Established in 1970 & 1 \\
\hline CLFR 2-Manchester & $\begin{array}{c}\text { Co-operative } \\
\text { (Workers) }\end{array}$ & Established in 1996 & 1 \\
\hline CLFR 3-Manchester & Social enterprise & Established in 2014 & 1 \\
\hline $\begin{array}{c}\text { CLFR-Greater } \\
\text { Manchester }\end{array}$ & $\begin{array}{l}\text { Co-operative } \\
\text { (Community) }\end{array}$ & Established in 2014 & 1 \\
\hline CLFR-Lancs & $\mathrm{CIC}$ & Established in 2013 & 2 \\
\hline CLFR 1-London & $\mathrm{CIC}$ & Established in 2010 & 1 \\
\hline CLFR 2-London & $\mathrm{CIC}$ & Established in 2013 & 2 \\
\hline CLFR-Brighton & $\mathrm{CIC}$ & Established in 2013 & 1 \\
\hline CLFR_Birmingham & $\begin{array}{l}\text { Co-operative } \\
\text { (Workers) }\end{array}$ & Established in 2009 & 1 \\
\hline CLFR-Glasgow & Social business & Established in 2011 & 5 \\
\hline CLFR_West Yorkshire & $\begin{array}{l}\text { Co-operative } \\
\text { (Consumer) }\end{array}$ & Established in 2009 & 1 \\
\hline CLFR-Nottingham & $\begin{array}{l}\text { Independent retailer } \\
\text { (Originally a } \\
\text { Consumer } \\
\text { Co-operative) }\end{array}$ & Established in 2008 & 1 \\
\hline CLFR 1-Edinburgh & Social business & Established in 2011 & 5 \\
\hline CLFR 2-Edinburgh & Social business & Established in 2013 & 1 \\
\hline
\end{tabular}

Recruitment criteria included organisations that were openly committed to community and social principles within a food retail context. Consent from participants was obtained and ethical approval was received from the first author's university prior to data collection. Despite all participants expressing their consent to be transparent and open regarding their commercial activities, individual participants have been anonymised.

Interviews lasted between $60 \mathrm{~min}$ and six hours, which amounted to a total of $850 \mathrm{~min}$ of audio recorded data. The interviews followed a semi-structured discussion guide, with topics that focused on the retail mission, business model, business challenges and goals, and community impact. After making verbatim transcriptions of the interviews, interview analysis involved an open coding system [65], and the development of initial themes, which were then revised and adjusted in the analytical process. Subsequently, inter-coder cross-checking of all interview transcripts was completed by using an external qualitative expert to facilitate the identification, development, and refinement of themes [66].

Within this data analysis process, we adopted an iterative process whereby first order concepts were generated that were then refined as second order themes and aggregate thematic dimensions [59], as illustrated in Figure 1. Thus, we sought interpretive quality by considering the potential contributions of our research, discussing and comparing relevant data interpretations and interpretive tensions, respecting participants' voices and practices, and providing evidence of emerging interpretations through our writing strategy [67]. The following section draws on participants' quotations and discusses our interpretation of our themes. 


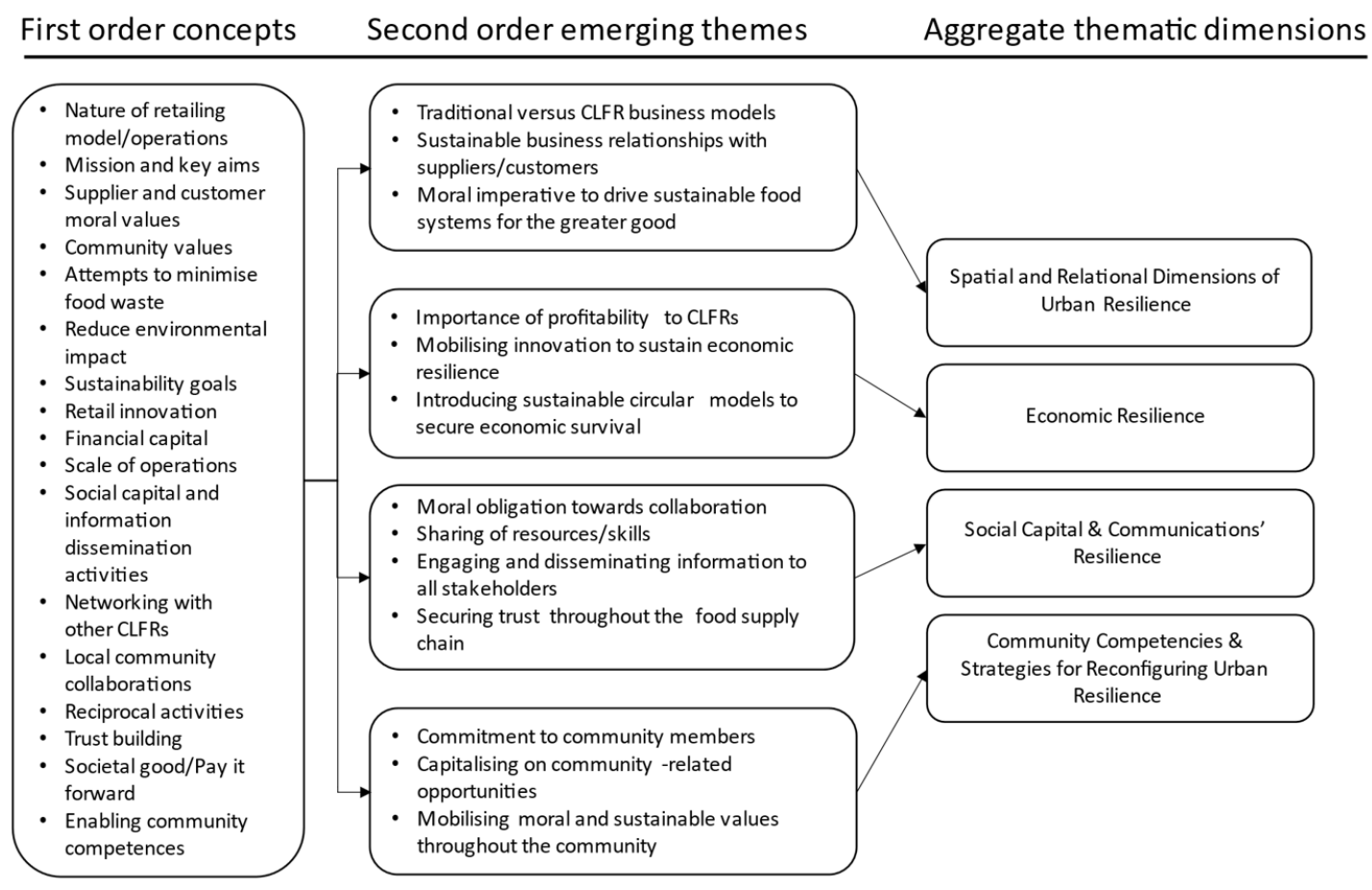

Figure 1. Data Analysis Structure.

\section{Findings and Discussion}

Drawing on Norris et al.'s [1] (p. 127) "four primary sets of adaptive capacities", namely economic development, social capital, information and communication and community competence, our emerging themes considered the spatial and relational ties binding the retail and social systems within which these CLFRs operate. In so doing, we acknowledged Meerow et al.'s [38] conceptual tensions inherent in the concept of urban resilience and extended Norris et al.'s [1] conceptualization of community resilience by positing the central, integrated, and dynamic role played by an organisation's moral values and behaviour. As a result of incorporating this additional construct to the existing capacities, our extended conceptualization enabled a more dynamic and adaptive community-led retail system which allows for a more sustainable state of equilibrium (i.e., a food producing system which works in accordance with available resources without compromising the needs of future generations), thereby facilitating the transition and transformation of urban food systems. Figure 2 illustrates the conceptual role of sustainability stressors together with our added construct played by moral values and behaviour and other networked adaptive capacities, which we develop further in our discussions of the core themes that follow next.

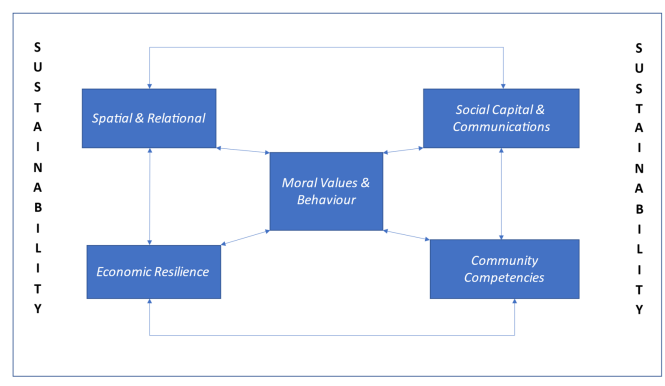

Figure 2. Sustainable Community Retail Resilience. * This figure builds on Norris et al.'s conceptualization of community resilience as a set of networked adaptive capacities [1] (p. 136). 


\subsection{Spatial and Relational Dimensions of Urban Resilience}

Representatives of the CLFRs interviewed regarded their organisations as situated within urban communities to which they made economic, social, and moral contributions. In this specific context, the notion of community was manifest both spatially and relationally. Following McEachern and Warnaby [22], the concept of community retailing amongst our CLFRs appeared broader than just a concentration on the local. More specifically, the immediate community extended beyond customers and residents within the retailer's catchment area to include also a community of [moral] values, evident at the local scale (e.g., people in the locale who shared the "conscious consumption" [68] ethos of the CLFRs), and also more widely (e.g., a broader network of CLFRs). Additionally, this extended to a supply chain community (e.g., organic and fair trade food producers), thereby indicating a broader, more diffuse spatiality beyond that of the immediate local retailing system.

As shown in the following quotes, a core area of agreement amongst all CLFRs was that their mission revolved around producing economic, social and environmental value in the form of a wider, sustainability-driven solution to the shortcomings of dominant food retail systems that generate food waste, excessive food miles, poor tasting foods, lack of seasonality, food illiteracy, and food-related social injustice [4,5,9,11,12]:

"We have always operated in complete contrast to the contemptible supermarket-led supply chains that promote the ritual disposal of colossal amounts of perfectly edible food"

(CLFR-Greater Manchester).

Consequently, many CLFRs referred to what they perceived as their transformative business models that focus on moral values such as accountability, fairness, transparency and doing things more sustainably, as highlighted below:

"The only sustainable model for retailing food for the future is social enterprise because it can't just be about short-term profit ... We've seen that model doesn't work. Pile it high and sell it cheap since the $60 \mathrm{~s}$, and now look at obesity and food related diseases and how many zillion kids with ADHD that can't concentrate at school, because they are not eating the right food. And it's all down to supermarkets ... they just pass the knock-on costs and impact to externalise the cost of doing our business in everything"

(CLFR-Brighton).

The above quotes show that CLFRs saw themselves as successfully competing in opposition to large retail businesses, and moreover, responding to adversity by seeking transformation [38], where efforts to build their own business resilience sought to purposefully reinvent and change an undesired system.

Indeed, despite their independent, small business status (and the consequent delimitation of their physical activities to the local scale), these CLFRs also sought a broader influence in scalar terms through their efforts to empower a broader community of values comprising a national, collective group of like-minded food retailers who collaboratively strive to re-insert food consumption and production within a social order, where shared values flexibly drive the impetus to address the perceived shortcomings of dominant and unjust systems of food provision. Furthermore, these CLFRs sought to build broader system resilience to achieve a positive economic, social, and moral impact across groups of people who may be at risk of poverty, and also across wider consumer communities of values. Here, CLFRs discussed at length their planned morally informed and sustainable activities to promote and facilitate food system resilience, not just at a local level, but also nationally and globally - often going beyond what would be expected from large food retailers and that which would be required by law:

"We have the 1\%, 4\% fund. With the 4\%-accepting that we are part of a global trading system and much of the harm is in the global south, we fund projects for groups... kind of securing their future with their community with skills or energy or their food experience. The 1\% is for community activities and they can be for various things"

(CLFR 2-Manchester). 
Also demonstrated in the above quote is a real sense of the experimental and innovative aspects of CLFRs as they attempted to mobilise societal and moral value for all their stakeholders to maximise retail resilience. Additionally, CLFRs expressed a strong commitment to securing sustainable and resilient urban retail systems, by looking to the longer-term impact of their roles within their communities, for example:

"Because we are fairly new, our immediate objective is to stay in business and treat our staff well to serve the community with what we've offered to the people who have bought it. I think the ideal would be to grow and develop and still be here in ten years' time ... But also to be doing more for the community who invested in the first place"

(CLFR-Greater Manchester).

CLFRs also contributed to community resilience more specifically, and we draw on Norris et al.'s [1] adaptive capacities of economic development, social capital, information and communication, and community competence to discuss their economic and social contributions while also highlighting their moral and sustainable capacities.

\subsection{Economic Resilience}

The integration and circularity of financial capital together with a commitment to sustainability and societal responsibility were overtly apparent throughout our conversations with CLFRs. Indeed, despite their smaller scale of operations, some CLFRs argued that their capabilities in relation to equitable pricing and the quality of their food are superior to similar products sold by the larger retail multiples:

"[Our] buying power isn't as big as theirs [the retail multiples] ... but we have a special relationship with other co-operatives, so our organic eggs are much cheaper than [major UK food retailer]; and our wall of beans when you come in the shop, beat any [major UK food retailer] hands down, because it's all organic"

(CLFR1-Manchester).

The articulation of such sentiments implicitly encapsulated a desire for a resilient food retail system that also delivers on wider sustainability goals, such as poverty. Here, CLFR 2 (Edinburgh) discussed how they collect surplus food to re-package and re-process that is then sold to a variety of customers (in some cases to extremely affluent consumers), rather than just those living in poverty:

"It's a 100 per cent intercepted food... If people have got no money and they walk in, they'll get fed ... it's ended up getting a lot of press, which is great...sometimes we can get between $£ 5$ and $£ 10$ a head depending on who your customers are"

(CLFR 2-Edinburgh).

In contrast to larger food retailers, CLFRs largely identified themselves as promoting a more circular and thereby sustainable, moral (i.e., "do what's right"), and more resilient notion of wealth creation as opposed to more traditional retailer business models:

"What gives me confidence and strength, is knowing that these initiatives are coming from small start-ups, social enterprises that have been started with values, decency at the core of their model. Trying to do what's right, rather than trying to profit maximise and that for me represents quite an exciting shift in business ... So that probably is a big difference in the kind of social enterprise sector compared to traditional capitalist systems"

(CLFR 3-Manchester).

These moral obligations and sustainability-driven solutions to the shortcomings of dominant food retail systems $[4,5,9,11,12]$ provided further evidence of CLFRs' capacity to adapt and/or reinvent their retail systems in the face of persistent economic and societal stressors.

\subsection{Social Capital, Communications and Resilience}

Due to a high degree of overlap between social capital and information and communication, the two capacities are amalgamated here. CLFRs invest significantly in-and 
generate-human, social, and intellectual capital in order to operate. In particular, there is much evidence of the cognitive dimension of social capital [69] across CLFRs, as it relates to the sharing of resources, skills, and sustainability goals [70,71], particularly the sharing of knowledge in an educational context. For example, CLFR (West Yorkshire) talked at length about the close links between their business and schools, and how they participate in talks and practical activities around growing and cooking food. For example, "The schools come to us. They know they can come down to us and if anybody wants us to go and talk at assembly there would be somebody willing to go and do it to explain things" (CLFR-West Yorkshire). Another CLFR talked about how they engaged not just schoolchildren, but also their parents:

"We've done school scenarios where I've gone to talk to a collection of parents; six/seven is the ideal age. It's a ten-week project, they have to go and research food waste. They have to go and find their own suppliers... I get them to negotiate with the kitchen and then the day before the dinner's due I go and see what they've collected, and I bring what else is needed to make it into nice food. Then I knock it up ... I've loved the school events"

(CLFR 2-Edinburgh).

As shown in the following quote, other CLFRs mentioned their social capital contributions in the form of knowledge sharing to foster food-related life skills for adults:

"In September 2010, the store acquired a complete ex-demonstration domestic kitchen ... Our members are gaining life skills through direct hands-on working in the kitchen, including food hygiene training, cookery lessons and teamwork"

(CLFR-London).

These quotes suggest that social capital was clearly facilitating actions around food provision and consumption that could benefit CLFRs, individuals, groups and the wider community through trust and reciprocity among enterprising and educational organisations, and through the dissemination of effective food-related information as well as knowledge, which leads to shared norms [72] and can contribute to overall resilience of the urban retail system.

Further, our findings also illustrated the structural dimensions of social capital [69], where there was much evidence placed on the "bonding" and "bridging" of business networks to help create strategic alliances [73], to enhance overall retail system resilience. As Norris et al.'s [1] capacity of social capital incorporates a sense of community, both social capital and moral value was also discussed by CLFRs while emphasizing the collective nature of their business governance structure, for example:

"Legally speaking there's just myself, but I estimate there's about maybe fifteen people in various different capacities working on the project and I've had some great support as well from the School for Social Entrepreneurs who back social enterprises up and down the UK"

(CLFR 3-Manchester).

Additionally, CLFR 2 (Manchester) acknowledged the importance of generating alliances, social membership, and a sense of community, which are intrinsic components of social capital [72,74]:

"We owe a lot to other co-operators who have helped to set us up, which is one of the great things about the Co-op movement, really. We are really unique in that we've cornered this collective kind of governance of our business... We are trying to spend this year looking at ways that we can keep this kind of structure with that engagement and keep it dynamic and get the new members to feel as closely; as much ownership of people who have been there longer"

(CLFR 2-Manchester).

The relational [69] and reciprocal nature of these alliances was extremely prominent. For example, CLFR (Brighton) claimed that "social enterprise more than anything is a complete 
pay-it-forward culture. So, we got so much help ... so much support that now, it's all the way along we've supported other social enterprises" (CLFR-Brighton).

The structural dimension in social capital appraises the quantity of relationships and the relational dimension helps to assess the quality of relationships, especially the development of trust in CLFRs $[75,76]$. While the CLFRs displayed evidence surrounding the structural dimension of social capital, the findings also reflected much evidence of social capital's relational aspects, especially concerning the development of trust between suppliers. As CLFR networks share common goals (i.e., commitment to social and sustainable causes), moral values, and mutual respect, these factors often result in greater public trust compared to big business [77]. For example, CLFR (Birmingham) talked about how they went about building their trust-based relationships with their suppliers:

"We try and choose our suppliers quite carefully. So, we use a local supplier for the flour and one from the Cotswolds... We don't have any contracts with any of our suppliers. We set up regular orders with them and so they know that they are likely to get orders from us every week or every fortnight, but they have no guarantee that we are going to order... It's all done on trust"

(CLFR—Birmingham).

Similarly, CLFR 3 (Manchester) spoke of the trust-based collaboration with another social enterprise to help achieve community resilience through positive, synergistic societal and sustainable impact:

"One of the reasons we like to work with a national food distribution network is that they by and large are now supporting projects whereby we also cook for people. It's less of an older style handout system whereby someone would just turn up and receive maybe ten different items. The food goes to a community project or groups, say, for example, a rehabilitation centre where a meal is cooked, and people go along, and they eat and it's the added benefit of having social interaction as well as getting a meal"

(CLFR 3-Manchester).

Thus, our findings support previous research that suggests social capital is perceived metaphorically as both a "glue and a lubricant" [78] (p. 207), facilitating moral and sustainable actions to benefit individuals, groups and the community through the "presence of trust, reciprocity and mutuality, shared norms of behaviour, shared commitment and belonging, formal and informal social networks, and effective information channels" $[71,72,79]$ (pp. 74-75), and as such, contributing to retail system resilience.

However, as documented earlier, existing research on community resilience and social capital makes little distinction between trust that may result in negative societal outcomes and trust which is pursued morally and for societal good [70,76]. While we recognise that social capital does not always lead to being responsible to and for others [70,79], our findings resonate with the type of social capital that Gupta et al. [76] allude to that takes responsibility for others, with a positive societal and sustainable orientation [70], at both a local community and national level. Thus, this enables the crystallisation of more dynamic and potentially transformative competences at the community level.

\subsection{Community Competences and Strategies for Reconfiguring Urban Resilience}

As our CLFRs spoke of their need to provide a sustainable alternative to large food retailers and their current food retail provision, there is much evidence to suggest that CLFRs endeavour to create a distinct type of urban retail resilience. For example, CLFR 1 (Manchester) emphasised the added social, moral, and sustainable competences that they possess regarding their retailing activities. One example which demonstrates retail flexibility, community empowerment, and action as discussed by CLFR 1 (Manchester) is their engagement in complementary activities associated with the retailing of healthcare products, whereby they helped customers decipher medical prescriptions and identify appropriate homeopathic products for their health ailments: 
"I get people sticking out their tongues and showing me their rashes and things like that ... It's a big part of the business ... there's myself and another clinical nutritionistpeople get a service here that they would get really in a clinic. People regularly bring me in their blood results ... or ask me whether to go and test it with a GP. Not everybody can afford to go and see a nutritionist"

(CLFR 1-Manchester).

Resonating with Baker et al. [49], this quote illustrates CLFR 1's intentional moral action in the marketplace, seeking to produce positive outcomes for the local community in which they operate. Similarly, many CLFRs discussed at length their sustainability competences (which also integrate economic development, social capital and information and communication capacities) aimed at achieving positive community resilience outcomes:

"The shop closes at 3 pm and we do our cashing up and stuff and then the homeless kind of queue up outside. Everything that's left over gets distributed fairly between all the homeless people, so nothing goes to waste from the shops. Then from four o'clock on a Monday we do our Social Suppers so that's when most of them come in. They can sit, they can have dinner. We have Big Issue, Shelter Scotland support workers here who are willing to help and offer any advice. We also partner up with Shelter Scotland as well so that if a homeless person was to come in and speak to us about being homeless, we can pass the details of all the other organisations where they can go to"

(CLFR-Glasgow).

Similarly, as demonstrated by the following quote, there is a conscious attempt amongst CLFRs to develop community competences further:

"If somebody from outside our area wanted bread and they wanted it delivered and stuff we'd just say, no. There is other businesses in the area that can do that ... I personally like the fact that we know who is eating our bread and have got a relationship with our customers that come in. We know their children and their dogs and all the rest of it. It's a proper community kind of shop ... We are not set up to supply restaurants and cafes and stuff. We could do, there is a lot of money to be made potentially doing that, but that's not us"

(CLFR—Birmingham).

The above quotes from CLFRs echo Baron et al.'s [48] concept of community to incorporate both territorial and non-territorial attributes. Consequently, these attributes and community competences were expressed publicly by communicating moral values such as fairness, accountability, reciprocity, and transparency, demonstrating their moral consciousness, shared values, and traditions [49], and a moral commitment to society at the community level and beyond. More importantly, these competences and commitment from CLFFRs indicate a representation of retailing conflicting with that of the large food retailers who are perceived as being "increasingly divorced" from their communities [3] (p. 10).

On the basis of the above findings and discussion, the following section outlines our conclusions, implications and relevant recommendations. These are suggested to help CLFRs secure a more sustainable set of capacities needed to ensure resilient urban retail systems which benefit local communities.

\section{Conclusions, Recommendations and Avenues for Future Research}

Due to limited research concerning retail communities [26] and calls for more research into the role of community in the marketplace [33] and community resilience [1,21], this study contributed theoretically by establishing the complex links between community, place, social relations, moral values, and resilience that manifest through CLFRs. In contrast to the contentious relationships [4], damaging environmental impacts [5], and encouragement of unsustainable consumption behaviors [6-8] that have been documented in relation to large food retail organizations, our findings highlighted CLFRs' drive to challenge the dominant 
modus operandi of large food retailers and re-embed retailing within a more sustainable and resilient food production system.

Drawing on spatial and relational theories of resilience, our research demonstrated that these retailers actively implemented transformative business models that aimed to engage and integrate community members to produce moral, sustainable, and resilient solutions at the local level to the shortcomings of dominant food retail systems. The networked capacity of CLFRs for social capital, strategic alliances, and information dissemination while generating a sense of community additionally contributes to the overall resilience of the urban food retail system.

Consequently, our contribution to the field of urban retail systems is twofold. Firstly, this research responded to Moufahim et al.'s [33] and Nguyen and Akerkar's [21] call for further research on manifestations of community in the marketplace and community resilience, respectively, enabling us to establish a more nuanced understanding of how they manifest through CLFRs. Secondly, by incorporating Meerow et al.'s [38] conceptual tensions within the concept of urban resilience, we extended Norris et al.'s [1] conceptualization of community resilience by establishing moral values and behaviour as an additional adaptive capacity required to deliver community resilience (see Figure 2).

Resonating with the second of Meerow et al.'s [38] conceptual tensions of urban resilience and De Verteuil and Golubchikov [55], we argue that our conceptualization enables a more dynamic and adaptive, community-led, resilient approach to urban food retailing which permits the potential transition from an unsustainable food system to a more transformative urban food retail system. Our research can be considered especially relevant given recent attention to sustainable development goals [56], as external factors (e.g., in a UK context: food shortages, Brexit, COVID-19) have drawn attention to the scale of international sourcing of foodstuffs and the importance of securing foodstuffs using shorter and more resilient supply chains, thus, providing further information dissemination opportunities for CLFRs to communicate their sustainable and community-led credentials.

As seen in other European contexts [80], our research points to further opportunities for small, independent retailers to explore the potential of cross-sector partnerships (especially with policymakers and urban planners) to help increase competitiveness as well as secure greater environmental and social impact in the local retail marketplace, in order to raise broader awareness of the issues that currently create some of the biggest challenges faced by society and how the impact of these issues may be mitigated. Although in this paper we have focused on food retailing, there is potential for future research to examine similar retailers operating in retail sectors other than food, which may also prove useful for revealing additional related adaptive capacities needed to theorise and research urban and community resilience.

Author Contributions: Conceptualization, M.G.M. and G.W.; methodology, M.G.M. and C.M.; formal analysis, M.G.M., C.M. and G.W.; investigation, M.G.M.; data curation, M.G.M., C.M. and G.W.; writing—original draft preparation, M.G.M., C.M. and G.W.; writing—review and editing, M.G.M., C.M. and G.W.; project administration, M.G.M..; funding acquisition, M.G.M. All authors have read and agreed to the published version of the manuscript.

Funding: This research project was funded by the Academy of Marketing Research Fund 2015-16.

Institutional Review Board Statement: Not applicable.

Informed Consent Statement: As described in the Methodology section of the paper, all areas of ethical approval (including informed consent) were approved by the University of Huddersfield.

Data Availability Statement: Data can be made available on request.

Conflicts of Interest: All authors declare that they have no conflict of interest. 


\section{References}

1. Norris, F.H.; Stevens, S.P.; Pfefferbaum, B.; Wyche, K.F.; Pfefferbaum, R.L. Community resilience as a metaphor, theory, set of capacities, and strategy for disaster readiness. Am. J. Community Psychol. 2008, 41, 127-150. [CrossRef]

2. Barata-Salgueiro, T.; Guimarães, P. Public Policy for Sustainability and Retail Resilience in Lisbon City Center. Sustainability 2020, 12, 9433. [CrossRef]

3. Sparks, L. Towns, High Streets and Resilience in Scotland: A question for policy? Sustainability 2021, 13, 5631. [CrossRef]

4. Thornton, M.L.; Esper, T.; Morris, M. Exploring the impact of supply chain counterproductive work behaviours on supply chain relationships. Int. J. Phys. Distrib. Logist. Manag. 2013, 43, 786-804. [CrossRef]

5. Manna, V.; Ulusoy, E.; Batat, W. New paths in researching "alternative" consumption and well-being in marketing: Alternative food consumption/Alternative food consumption: What is "alternative"?/Rethinking "literacy" in the adoption of AFC/Social class dynamics in AFC. Mark. Theory 2016, 16, 561.

6. Chkanikova, O.; Mont, O. Overview of Sustainability Initiatives in European Food Retail Sector; Lund University: Lund, Sweden, 2011.

7. Peter, P.C.; Batat, W.; Ulusoy, E. Rethinking 'literacy' in the adoption of AFC. Mark. Theory 2016, 16, 565-568.

8. WRAP. Quantification of Food Surplus, Waste and Related Materials in the Grocery Supply Chain; WRAP: London, UK, 2016.

9. Robbins, G.E.; Page, M.A. Sustainability initiatives: A competing values framework. Compet. Forum 2012, $10,176$.

10. Jones, P.; Comfort, D.; Hillier, D. Moving towards sustainable food retailing"? Int. J. Retail. Distrib. Manag. 2008, 36, 995-1001. [CrossRef]

11. Calderwood, E.; Davies, K. The trading profiles of community retail enterprises. Int. J. Retail. Distrib. Manag. 2012, 40, 592-606. [CrossRef]

12. Jones, P.; Hillier, D.; Comfort, D. In the public eye: Sustainability and the UK's leading retailers. J. Public Aff. 2013, 13, 33-40. [CrossRef]

13. Dawson, J.; Findlay, A. Sparks, L. The Retailing Reader; Routledge: London, UK; New York, NY, USA, 2008.

14. Cachinho, H. Consumerscapes and the resilience assessment of urban retail systems. Cities 2014, 36, 131-144. [CrossRef]

15. Burt, S.L.; Sparks, L. Power and competition in the UK retail grocery market. Br. J. Manag. 2003, 14, 237-254. [CrossRef]

16. Wrigley, N.; Brookes, E. Evolving High Streets: Resilience \& Reinvention: Perspectives from Social Science; ESRC/University of Southampton: Southampton, UK, 2014.

17. Wrigley, N.; Lambiri, D.; Astbury, G.; Dolega, L.; Hart, C.; Reeves, C.; Thurstain-Goodwin, M.; Wood, S. British High Streets: From Crisis to Recovery? A Comprehensive Review of the Evidence; ESRC/University of Southampton: Southampton, UK, 2015.

18. Wrigley, N.; Wood, S.; Lambiri, D. Corporate convenience store development effects in small towns: Convenience culture during economic and digital storms. Environ. Plan. A 2019, 51, 112-132. [CrossRef]

19. Holweg, C.; Lienbacher, E.; Zinn, W. Social Supermarkets-A new challenge in supply chain management and sustainability. Supply Chain Forum Int. J. 2010, 11, 50-58. [CrossRef]

20. BRC. A Vision for the UK Retail Industry: Delivering for Shoppers, Employers and the Economy. 2021. Available online: https: / / www.brc.org.uk/a-vision-for-the-UK (accessed on 9 June 2021).

21. Nguyen, H.L.; Akerkar, R. Modelling, measuring, and visualising community resilience: A systematic review. Sustainability 2020, 12, 7896. [CrossRef]

22. McEachern, M.G.; Warnaby, G. Community Building Strategies of Independent Co-operative Food Retailers. In Case Studies in Food Retailing and Distribution; Byrom, J., Medway, D., Eds.; Elsevier Oxford: Oxford, UK, 2018.

23. Coca-Stefaniak, A.; Hallsworth, A.G.; Parker, C.; Bainbridge, S.; Yuste, R. Decline in the British small shop independent retail sector: Exploring European parallels. J. Retail. Consum. Serv. 2005, 12, 357-371. [CrossRef]

24. Megicks, P.; Warnaby, G. Market orientation and performance in small independent retailers in the UK. Int. Rev. Retail Distrib. Consum. Res. 2008, 18, 105-119. [CrossRef]

25. Clarke, I.; Banga, S. The economic and social role of small stores: A review of UK evidence. Int. Rev. Retail. Distrib. Consum. Res. 2011, 20, 209-237. [CrossRef]

26. Smith, A.; Sparks, L. The role and function of the independent small shop: The situation in Scotland. Int. Rev. Retail Distrib. Consum. Res. 2000, 10, 205-226. [CrossRef]

27. McArthur, E.; Weaven, S.; Dant, R. The evolution of retailing: A meta review of the literature. J. Macromarketing 2016, 36, 272-286. [CrossRef]

28. Rahman, M.; Hussain, M. Social business, accountability, and performance reporting. Humanomics 2012, 28, 118-132. [CrossRef]

29. Peredo, A.M.; Chrisman, J.J. Toward a theory of community-based enterprise. Acad. Manag. Rev. 2006, 31, 309-328. [CrossRef]

30. Martin, F.; Thompson, M. Social Enterprise: Developing Sustainable Business; Palgrave-MacMillan: Basingstoke, UK, 2010.

31. Haugh, H. A research agenda for social entrepreneurship. Soc. Enterp. J. 2005, 1, 1-12. [CrossRef]

32. Yunus, M.; Moingeon, B.; Lehmann-Ortega, L. Building social business models: Lessons from the Grameen experience. Long Range Plan 2010, 43, 308-325. [CrossRef]

33. Moufahim, M.; Wells, V.; Canniford, R. JMM Special Issue Call for Papers; special Issue on The Consumption, Politics and Transformation of Community. 2017. Available online: http:/ / www.jmmnews.com/the-consumption-politics-and-transformation-ofcommunity / (accessed on 6 February 2017).

34. Golubchikov, O. Persistent resilience. Coping with the mundane pressures of social or spatial exclusion: Introduction to a special session. In Proceedings of the RGS-IBG Annual International Conference, London, UK, 1-5 August 2011. 
35. Aubry, C.; Kebir, L. Shortening food supply chains: A means for maintaining agriculture close to urban areas? The case of the French metropolitan area of Paris. Food Policy 2013, 41, 85-93. [CrossRef]

36. McEachern, M.G.; Warnaby, G.; Carrigan, M.; Szmigin, I. Thinking locally, acting locally? Conscious consumers and farmers' markets. J. Mark. Manag. 2010, 26, 395-412. [CrossRef]

37. Coaffee, J. Towards next-generation urban resilience in planning practice: From securitization to integrated place making. Plan. Pract. Res. 2013, 28, 323-339. [CrossRef]

38. Meerow, S.; Newell, J.P.; Stults, M. Defining urban resilience: A review. Landsc. Urban Plan. 2016, 147, 38-49. [CrossRef]

39. Stumpp, E. New in town? On resilience and 'Resilient Cities'. Cities 2013, 32, 164-166. [CrossRef]

40. Cutter, S.; Barnes, L.; Berry, M.; Burton, C.; Evans, E.; Tate, E.; Webb, J. A place-based model for understanding community resilience to natural disasters. Glob. Environ. Chang. 2008, 18, 598-606. [CrossRef]

41. Desouza, K.; Flanery, T. Designing, planning, and managing resilient cities: A conceptual framework. Cities 2013, 35, 89-99. [CrossRef]

42. Leitner, H.; Sheppard, E.; Webber, S.; Colven, E. Globalizing urban resilience. Urban Geogr. 2018, 39, 1276-1284. [CrossRef]

43. Star, S.L.; Griesemer, J.R. Institutional ecology 'translations' and boundary objects: Amateurs and professionals in Berkeley's Museum of Vertebrate Zoology, 1907-1939. Soc. Stud. Sci. 1989, 19, 387-420. [CrossRef]

44. Wardekker, A.; Wilk, B.; Brown, V.; Uittenbroek, C.; Mees, H.; Driessen, P.; Wassen, M.; Molenaar, A.; Walda, J.; Runhaar, H. A diagnostic tool for supporting policymaking on urban resilience. Cities 2020, 101, 102691. [CrossRef]

45. Grinberger, A.; Felsenstein, D. Bouncing back or bouncing forward? Simulating urban resilience. Urban Des. Plan. 2014, 167,'115-124. [CrossRef]

46. Baker, S.; Baker, C.N. Narratives of cultural trauma (and resilience): Collective negotiation of material wellbeing in disaster recovery. In NA-Advances in Consumer Research, 42th ed.; June, C., Stacy, W., Eds.; Association for Consumer Research: Duluth, MN, USA, 2014; pp. 7-8.

47. Azarya, V. Community. In The Social Science Encyclopaedia, 2nd ed.; Kuper, A., Kuper, J., Eds.; Routledge: London, UK; New York, NY, USA, 1996; pp. 114-115.

48. Baron, S.; Conway, T.; Warnaby, G. Relationship Marketing: A Customer Experience Approach; Sage: Los Angeles, CA, USA; London, UK; New Delhi, India; Singapore; Washington, DC, USA, 2011.

49. Baker, S.M.; Hunt, D.M.; Rittenburg, T.L. Consumer vulnerability as a shared experience: Tornado recovery process in Wright, Wyoming. J. Public Policy Mark 2007, 26, 6-19. [CrossRef]

50. Muniz, A.M.; O'Guinn, T.C. Brand community. J. Consum. Res. 2001, 27, 412-432. [CrossRef]

51. Ozanne, L.; Ozanne, J.L. How alternative consumer markets can build community resiliency. Eur. J. Mark. 2016, 50, 330-357. [CrossRef]

52. Goulding, C.; Kelemen, M.; Kiyomiya, T. Community based response to the Japanese tsunami: A bottom-up approach. Eur. J. Oper. Res. 2018, 268, 887-903. [CrossRef]

53. Szmigin, I.T.; O’Loughlin, D.M.; McEachern, M.; Karantinou, K.; Barbosa, B.; Lamprinakos, G.; Fernández-Moya, M.E. Keep calm and carry on: European consumers and the development of persistent resilience in the face of austerity. Eur. J. Mark. 2020, 54, 1883-1907. [CrossRef]

54. Longstaff, P.H. Security, Resilience, and Communication in Unpredictable Environments such as Terrorism, Natural Disasters, and Complex Technology. Program on Information Resources Policy; Harvard University, Centre for Information Policy Research: Harvard, UK, November 2005; pp. 1-103.

55. De Verteuil, G.; Golubchikov, O. Can resilience be redeemed? City 2016, 20, 143-151. [CrossRef]

56. Keitsch, M. Structuring ethical interpretations of the sustainable development goals-Concepts, implications and progress. Sustainability 2018, 10, 829. [CrossRef]

57. Martin, R. Regional economic resilience, hysteresis and recessionary shocks. J. Econ. Geogr. 2012, 12, 1-32. [CrossRef]

58. Bansal, P.; Corley, K. The coming of age for qualitative research: Embracing the diversity of qualitative methods. Acad. Manag. J. 2011, 54, 233-237. [CrossRef]

59. Gioia, D.A.; Corley, K.G.; Hamilton, A.L. Seeking qualitative rigor in inductive research: Notes on the Gioia methodology. Organ. Res. Methods 2013, 16, 15-31. [CrossRef]

60. Jamali, D.; Zanhour, M.; Keshishian, T. Peculiar strengths and relational attributes of SMEs in the Context of CSR. J. Bus. Ethics 2009, 87, 355-377. [CrossRef]

61. Reinecke, J.; Arnold, D.G.; Palazzo, G. Qualitative methods in business ethics, corporate responsibility, and sustainability research Bus. Ethics Q. 2016, 26, xiii-xxii. [CrossRef]

62. Crouch, M.; McKenzie, H. The logic of small samples in interview-based qualitative research. Social Sci. Inf. 2006, 45, 483-499. [CrossRef]

63. Sen, S.; Cowley, J. The relevance of stakeholder theory and social capital theory in the context of CSR and SMEs: An Australian perspective. J. Bus. Ethics 2013, 118, 413-427. [CrossRef]

64. Mason, M. Sample size and saturation in PhD studies using qualitative interviews. Forum Qual. Soz. Forum Qual. Soc. Res. 2010, 11. [CrossRef]

65. Creswell, J.W. Research Design: Qualitative, Quantitative, and Mixed Methods Approaches; Sage: Thousand Oaks, CA, USA, 2009.

66. Miles, M.B.; Huberman, A.M.; Saldana, J.M. Qualitative Data Analysis: An Expanded Sourcebook; Sage: Thousand Oaks, CA, USA, 2014. 
67. Pratt, M.G. For the lack of a boilerplate: Tips on writing up (and reviewing) qualitative research. Acad. Manag. J. 2009, 52, 856-862. [CrossRef]

68. Nova-Reyes, A.; Muñoz-Leiva, F.; Luque-Martínez, T. The tipping point in the status of socially responsible consumer behavior research? A bibliometric analysis. Sustainability 2020, 12, 3141. [CrossRef]

69. Nahapiet, J.; Ghoshal, S. Social capital, intellectual capital and the organisational advantage. Acad. Manag. Rev. 1998, 23, $242-266$. [CrossRef]

70. Fuller, T.; Tian, Y. Social and symbolic capital and responsible entrepreneurship: An empirical investigation of SME narratives. J. Bus. Ethics. 2006, 67, 287-304. [CrossRef]

71. Merlo, O.; Bell, S.J.; Mengüç, B.; Whitwell, G.J. Social capital, customer service orientation and creativity in retail stores. J. Bus. Res. 2006, 59, 1214-1221. [CrossRef]

72. Kay, A. Social capital, the social economy and community development. Community Dev. J. 2003, 41, 160-173. [CrossRef]

73. Doherty, B.; Foster, G.; Mason, C.; Meehan, J.; Meehan, K.; Rotheroe, N.; Royce, M. Management for Social Enterprise; Sage: London, UK, 2014.

74. Bourdieu, P. The Forms of Capital. In Handbook of Theory and Research for the Sociology of Education; Richardson, J., Ed.; Greenwood: New York, NY, USA, 1986; pp. 241-258.

75. Adler, P.S.; Kwon, S.W. Social capital: Prospects for a new concept. Acad. Manag. Rev. 2002, 27, 17-40. [CrossRef]

76. Gupta, A.K.; Sinha, R.; Koradia, D.; Patel, R.; Parmar, M.; Rohit, P.; Chandan, A. Mobilizing grassroots' technological innovations and traditional knowledge, values and institutions: Articulating social and ethical capital. Futures 2003, 35, 975-987. [CrossRef]

77. Ridley-Duff, R.; Bull, M. Understanding Social Enterprise: Theory and Practice; Sage: London, UK, 2016.

78. Anderson, A.R.; Jack, S.L. The articulation of social capital in entrepreneurial networks: A glue or a lubricant? Entrep. Reg. Dev. 2002, 14, 193-210. [CrossRef]

79. Silkoset, R. Negative and positive effects of social capital on co-located firms' withholding efforts. Eur. J. Mark. 2013, 47, 174-197. [CrossRef]

80. Barata-Salgueiro, T. Shops with a history and public policy. Int. Rev. Retail. Distrib. Consum. Res. 2021, 1-18. [CrossRef] 